\title{
A study on the physical and mechanical properties of a granite outcrop for a quarry at Onikoko community, Oyo State, South-Western Nigeria
}

\author{
Luqman Kareem Salati ${ }^{1^{*} \otimes}$, Jacob Titilope Adeyemo ${ }^{2 \otimes}$ \\ ${ }^{1}$ Kaduna Polytechnic, Kaduna, 800211, Nigeria \\ ${ }^{2}$ Geocardinal Engineering Services Limited, Abuja, 900211, Nigeria \\ *Corresponding author: e-mail lksalati@gmail.com, tel.+2348065105559
}

\begin{abstract}
Purpose. To investigate the physical and mechanical properties of a granite outcrop for a quarry at Onikoko community in Oyo State, South-Western Nigeria.

Methods. Samples of granite rock were collected from the outcrop for the laboratory determination of their physical and mechanical properties required for determining its suitability for construction and engineering purposes, and the desired properties were determined.

Findings. Results from the tests conducted on the granite samples indicated the various values of physical and mechanical properties of the outcrop in the study area. The results obtained are found to be within the acceptable international standards. Hence, the granite outcrop is found to be suitable for establishing a quarry in the study area based on the results obtained.

Originality. The results in this study have affirmed the fact that granite rocks must possess adequate physical and mechanical characteristics to make them suitable for construction and engineering purposes. The physico-mechanical properties of the granite outcrop evaluated in this study having their values within the international standards attest to high strength characterization of the granite rock. The life span of the proposed quarry is established to be forty years, which is also an indication of rich mineralization of the area.

Practical implications. Results of this study can be a useful source of information to potential investors and policy makers for the establishment of a quarry in the study area. Hence, government's attention can be drawn to the needs of the host community for the provision of basic infrastructures.
\end{abstract}

Keywords: granite outcrop, physical and mechanical properties, quarrying operation

\section{Introduction}

The quarrying of aggregate stones such as granite has become a key stand for infrastructure projects including construction of roads and houses, bridges, paving monuments, amongst other uses. The use of granite has sparked increasing demands for granite aggregates in areas of infrastructural development such as road construction and structure building. Recent building decoration demands have partly increased granite consumption in many capital cities around the world [1]. The construction aggregate industry is an essential part of most developed economies [2]. Given the suitability of volcanic rock aggregates for concrete and the likelihood of alkali reactivity of granitic rocks, its suitability for use as a major source for crushed rock aggregate cannot be disregarded [3]. Granite aggregate possesses a variety of physical and chemical properties that determine its suitability as a material for construction [4]. Assessment of granitic outcrops for pos- sible quarrying may, therefore, require investigation of joint and fracture characteristics for assessment of block size.

Granite is a light-colored, igneous rock with grains that are large enough to be visible to the eye without help. It is formed from the slow crystallization of magma beneath the surface of Earth. Granite is massive, hard and tough, lacking an internal structure which makes it widely suitable for use as a stone of construction. Its compressive strength is typically above $200 \mathrm{MPa}$, with a viscosity similar to standard temperature and pressure (STP) of 3-6 $10^{19} \mathrm{~Pa} \cdot \mathrm{s}$ [5]. At ambient pressure, the melting temperature of dry granite is $1215-1260^{\circ} \mathrm{C}$ $\left(2219-2300^{\circ} \mathrm{F}\right)$; it is reduced sharply in the presence of water, down to $650^{\circ} \mathrm{C}$ at a few kBar pressure [6]. Granite has poor primary permeability but strong secondary permeability.

In any structural design, research into the physical and mechanical properties of rocks is an important consideration, especially for engineering purposes. Sections of what should be discussed include the parameters that influence the rock's

Received: 8 September. Accepted: 8 January 2021. Available online: 5 March 2021

(C) 2021. L.K. Salati, J.T. Adeyemo

Published by the Dnipro University of Technology on behalf of Mining of Mineral Deposits. ISSN 2415-3443 (Online) | ISSN $2415-3435$ (Print)

This is an Open Access article distributed under the terms of the Creative Commons Attribution License (http://creativecommons.org/licenses/by/4.0/),

which permits unrestricted reuse, distribution, and reproduction in any medium, provided the original work is properly cited. 
drilling state. The physical properties of coarse aggregates are related to the state of rock weathering from which they originated [7]. Physico-mechanical properties of rocks that are used as aggregates are the most relevant parameters for specific engineering purposes in every application and in its classification [8]. Physical and mechanical properties of rocks are also strongly dependent on void network. Such design should be planned according to structure type, load characteristics and strata properties of rock bearings [9].

Like other hard rocks, the physical and mechanical impacts of granitic rocks also have significant influence on the quarrying equipment in a number of ways, especially given the relationship between the physical and mechanical properties of rock and the power consumption of such equipment [10]. The design aspects and possibilities for sharing failures that must be studied are parts of the investigation. In a study by Adebayo and Adetula (2013) [11], it was established that uniaxial compressive strength, texture and grain size, drill rate index and equivalent quartz content (EQC) significantly affect rock drilling conditions. Appropriate laboratory tests, therefore, need to be carried out before the final design stage to assess the rock properties. Another study carried out by Agyeman et al. (2019) [12] is also in agreement that laboratory tests and material specification are essential to determine the suitability of rock aggregates to be used in construction. In view of the imperative to fulfill this important technical requirement, this study attempts to investigate the physical and mechanical properties of granite outcrop situated in Onikoko community near Oyo town, Oyo State, South-west of Nigeria. This is in order to assess its suitability for quarrying operation.

\section{Materials and methods}

\subsection{Brief description of the study area}

The Outcrop to be used for the proposed quarry project is located on a 20 hectare piece of land along old Ibadan Lagos road at Onikoko Village, which is less than $2 \mathrm{~km}$ to Olonde village and some kilometres away from Olubadan village close to Abanla in Oluyole Local Government of Oyo State, South-Western Nigeria. The proposed quarry site is at an economic distance from market environments and is within easy reach from different parts of the Ibadan metropolis and neighboring states surrounding Oyo State. The coordinates location is approximately between Latitudes $\left(07^{\circ} 15^{\prime} 15^{\prime}, \mathrm{N}\right)$ and $\left(07^{\circ} 15^{\prime} 34^{\prime \prime} \mathrm{N}\right)$ North of the equator and $003^{\circ} 50^{\prime} 42^{\prime \prime} \mathrm{E}$ and Longitudes (003 $\left.50^{\prime} 50^{\prime}, \mathrm{E}\right)$ East of the green winch meridian. The study site is rectangular in shape, generally adjusting to the boundaries of the adjoining plots. Its perimeter is delineated round with coordinates LB $03^{\circ} 49^{\prime} 15^{\prime \prime} \mathrm{N}$ and $07^{\circ} 11^{\prime} 30^{\prime \prime} \mathrm{E}, \mathrm{CB} 103^{\circ} 49^{\prime} 15^{\prime \prime} \mathrm{N}$ and $07^{\circ} 11^{\prime} 15^{\prime \prime} \mathrm{E}, \quad \mathrm{CB} 203^{\circ} 49^{\prime} 00^{\prime \prime} \mathrm{N}$ and $07^{\circ} 11^{\prime} 15^{\prime \prime} \mathrm{E}$ and CB3 03 ${ }^{\circ} 49^{\prime} 00^{\prime \prime} \mathrm{N}$ and $07^{\circ} 11^{\prime} 30^{\prime \prime} \mathrm{E}$.

Oyo State lies mostly on lowlands which are punctuated by rocky outcrops and series of hills. Most of the rock outcrops are located in areas around lseyin, Shaki, Sepeteri, Okeho and Igbeti. These are mainly of schist and quartzite inselbergs. According to Adekoya et al. (2011) [13], the PanAfrican granites (Older Granites), widely distributed in the South-Western parts of Nigeria, occur as minor syenite around the study area and are sources of construction materials, particularly rock aggregates used in road construction. Although Ogunyele and Akingboye (2018) [14] relate the
Pan-African older granite suite with the Nigerian tin-bearing pegmatite, Alayande et al. (2015) [15] allude to the presence of two granite generations within the basement rocks and categorizes the study area into the Western Nigerian Basement of which the basement rocks cover nearly 100 percent of the total land surface in Oyo State. Figure 1 shows a simplified map of Nigeria indicating the distributions of the three major geological components and Oyo State within the study area is located.

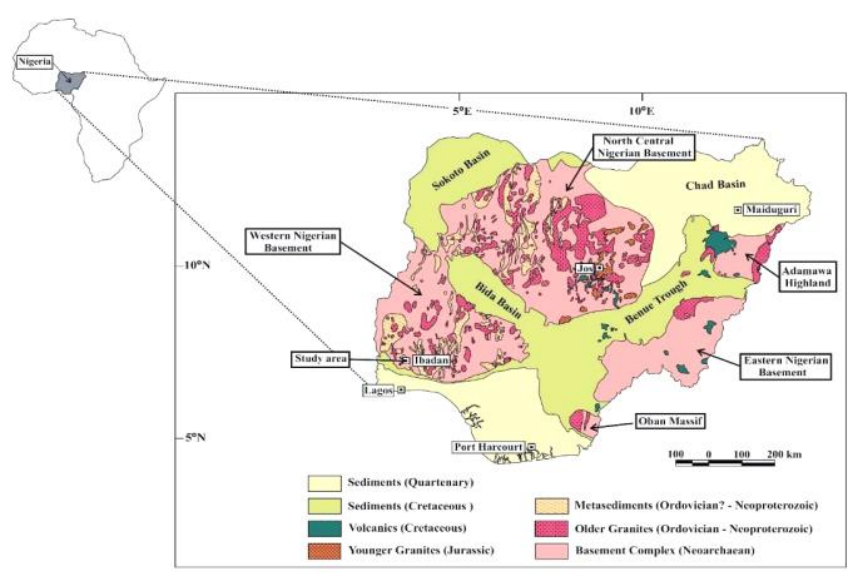

Figure 1. Simplified geological map of Nigeria showing the distributions of the three major geological components and Oyo state location [13]

The Granitic rock of the proposed Quarry Lease area has a felsic composition and is more common in recent geological times, as opposed to the ancient ultramafic igneous history of Earth (Fig. 2, 3). Felsic rocks are less dense than mafic and ultramafic rocks, and therefore tend to resist sub-duction, whereas basalt or gabbroic rocks continue to sink into the mantle under the continental cratons' granite rocks. Hence, granite rocks form the basement of all continents of the earth.
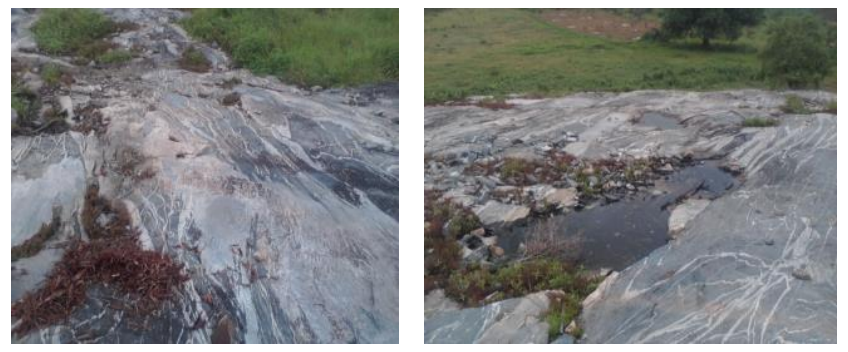

Figure 2. Exposure of parts of the granite outcrop in the study area showing its relief

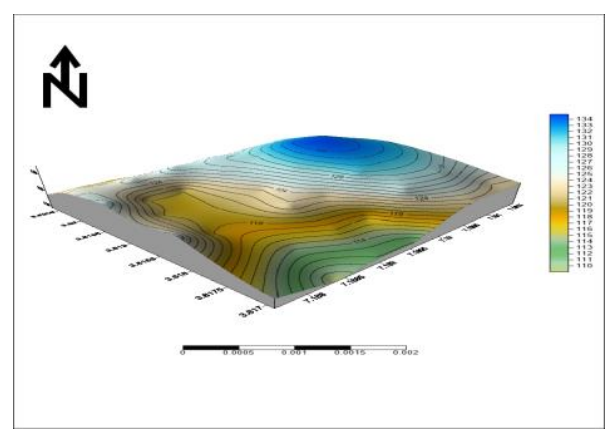

Figure 3. Topography of the proposed quarry site 
Granitic rock is abundant all over the continental crust. Much of it had been intruded during the Precambrian age; it is the most abundant basement rock underlying the continents' relatively thin sedimentary veneer. Granite outcrops tend to form torsoes and rounded massifs. Granites occur sometimes in circular depressions surrounded by a series of hills formed by the metamorphic aureole or hornfels. Granite often occurs as relatively small, in stock masses of less than $100 \mathrm{~km}^{2}$ and in batholites often associated with orogenic mountain ranges.

\subsection{Field studies and data collection}

Samples of granite rock were collected with the use of a sledge hammer from the outcrop located in the Onikoko area of Oyo State, South-West Nigeria and labeled with care. The samples collected for geotechnical tests were sent to the laboratory. The visual and aesthetic characteristics of granite rock deposits in the study area were assessed by their colour, texture, grain size and faults. These properties were determined in-situ on the field and samples collected from the deposit were studied visually and with the use of the hand lens to determine their colour and textures respectively. The examination procedures for identification of colour, luster and shape of the outcrops adequately described the characteristics of the predominant mineral in the samples [16] (Fig. 4).

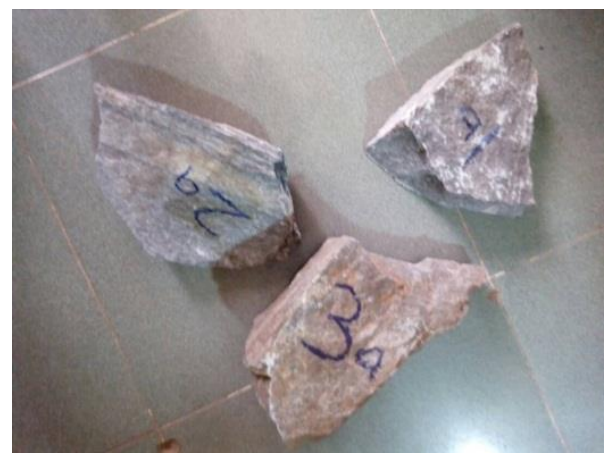

Figure 4. Labeled granite samples from the study site

The reserve estimation of the granite outcrop involved geological and geophysical surveys which comprised of geoelectric investigation basically involving electrical resistivity method using the Schlumberger configuration of vertical electrical sounding (VES) with the aid of Resistivity meter (Fig. 5). Electrical resistivity data were captured using terameter and other accessories and then processed and integrated to bring out the sub-surface information required. The method uses the ability of rock to conduct electric current which causes polarization when an electric current is passed through the rock. Hand-held Global Positioning System (GPS) and compass clinometers were also used to collect data for geophysical investigations (Fig. 6). The field data captured indicated three (3) to four (4) layer models all of which fall $2-10 \%$ resistivity and thickness accuracy. Software called Resisit was used quantitatively with computer iteration, and four type basic curves shapes were taken into consideration.

To determine the volume and tonnage of the granite outcrop, Equations 1 and 2 were adopted thus:

Volume $\left(\right.$ in $\left.\mathrm{m}^{3}\right)=\left(A_{1} A_{2} / 2\right) L$,

where:

$A_{1}$ and $A_{2}-$ the cross sectional areas of the outcrop;

$L-$ the perpendicular distance.

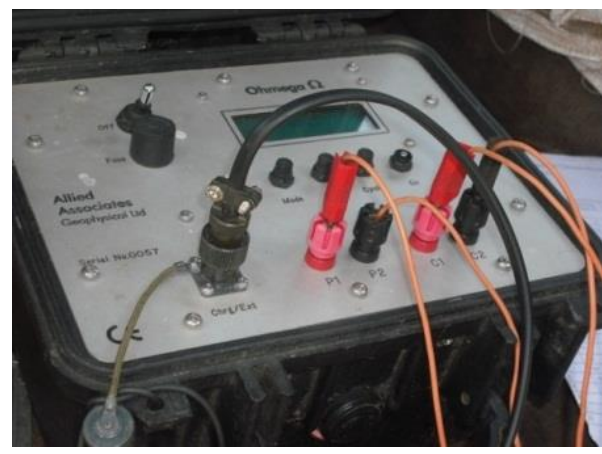

Figure 5. A typical resistivity meter (e.g. Ohmega)

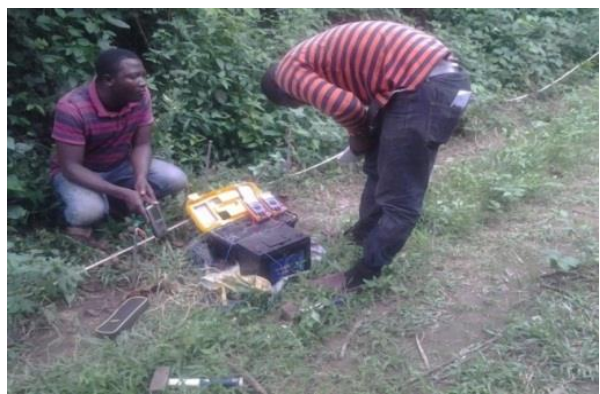

Figure 6. Data collection on the field

$T($ in tonnes $)=\left(A_{1} A_{2} / 2\right) L F$,

where:

$F$ - the tonnage factor of granite gneiss $\left(F\right.$ in $\left.\mathrm{t} / \mathrm{m}^{3}\right)$.

\subsection{Laboratory analysis}

Onikoko's granite outcrop was tested for physical and mechanical properties in accordance with the American Standard for Testing Materials (ASTM) D 2487 and the International Society for Rock Mechanics (ISRM) in order to determine the strength quality of the aggregate used for construction and engineering purposes. All the tests were carried out in the laboratory of Civil Engineering Department, Kaduna Polytechnic, North-western Nigeria. The following tests were performed on samples collected in order to assess the physical and mechanical properties of rock in the study area:

1) specific gravity (S.G.);

2) bulk density;

3) moisture content;

4) porosity;

5) water absorption;

6) brittleness;

7) aggregate crushing value (ACV);

8) uniaxial compressive strength (UCS);

9) point load strength index (IS);

10) slake durability test;

11) hardness;

12) abrasive test.

To determine the point load index of the rock, the following formula was adopted:

$$
I x x=\frac{P \cdot 1000}{(W \cdot D) \cdot 0.75 \sqrt{50}},
$$

where:

$I x x$ - point load strength index, MPa;

$P$ - applied load at failure, $\mathrm{kN}$;

$W$ - width of the sample, $\mathrm{mm}$; 
$D$ - height of the sample, $\mathrm{mm}$.

Determining the uniaxial compressive strength of the rock, Equation 4 was adopted in accordance with ISRM (1981) [17] and ASTM (2001) [18] D 2938 standards:

$C o=\frac{P}{A}=\frac{P}{(W \cdot D)}$,

where:

Co - uniaxal compressive strength, $\mathrm{MPa}$;

$P$ - the applied peak load, $\mathrm{kN}$;

$W$ - width of the sample, $\mathrm{mm}$;

$D$ - height of the sample, $\mathrm{mm}$.

Cylindrical core samples were prepared from the rock samples collected from the granite outcrops for the determination of the uniaxial compressive strength of the granite rocks of the two locations. The tests were performed under free laboratory atmospheric conditions because the objective was to relate laboratory tests to field conditions. Irregular block samples were also prepared from the samples of the outcrop collected from the field. The samples were thereafter tested to determine the tensile strength of the rock using Point Load Tester. The determination of slake durability of the granite rock from the two deposits was also carried out in the laboratory.

In this study, hardness of the rock was determined with the use of mechanical tools. Samples of the granite rock collected from the field were prepared in the laboratory and tested to standard for hardness with the use of Schmidt Hammer Rebound Value. The laboratory procedures suggested by Adebayo et al. (2010) [19] concerning uniaxial compressive strength, point load strength index and Schmidt Rebounds Hardness Value based established by ISRM (1981), ASTM (2001) D 2938 and ASTM D 5731 standards, and Jacobsson (2007) [20] for intact rock uniaxial compression test were adopted in this study to ensure accuracy of results. The ISRM suggested mode - I fracture toughness testing method as elaborated by [21] was also considered for determining fracture toughness of the rock samples. In order to assess the uniaxial compressive strength of the rock samples, the Schmidt hammer ( $\mathrm{SH}$ ) method was used to estimate the UCS of discontinuity walls and to test the workability, excavation and bore-ability of rocks by mechanical means (cutting, polishing, milling, crushing and fragmentation processes in quarrying) as suggested in the work carried out by [22]. The standard N-type hammer was used to create an impact on the rock sample by releasing energy.

The electrical resistivity method used in this study involved injecting controlled electric current into the ground from the electrode arrangement and measuring the corresponding signals and impulses. The eight different points where there were no visible traces of the up-shoot (outcrop) of the granitic body were sounded in order to determine depth of the overburden to granitic - gneiss basement. Vertical Electrical Sounding (VES) data sets were subjected to two phase interpretation processes of curve - matching and iterative inversion methods (layered earth modeling).

The cross section method was employed in estimating the delineated Onikoko granitic-gneiss reserve. Areas of influence were represented by the base areas of a cross section of some predetermined thickness. In this method, the mineral reserve calculation procedures adopted are as follows:

1) determination of mineral area in all the sections using plainimeter irregular outlines and other geometrical schemes;
2) calculation of average values of each section by using length - weight sample value average or using arithmetic average of sample values;

3) computation of volume for each block.

\section{Results and discussion}

Results of investigations carried out on the granite samples collected in the study area indicate that the granite rock's specific gravity is 2.7 . As shown in Table 1, the density of the bulk is found to be $2326 \mathrm{~kg} / \mathrm{m}^{3}$, and can be classified high. The Table 1 also shows that the moisture content range of the rock is between $0.060-0.079 \%$ yielding a mean value of $0.077 \%$, while the aggregate crushing value (ACV) of the rock ranges between 12.20-18.37, and with a mean value of $14.54 \%$.

Table 1. Density, moisture content and average aggregate crushing values $\left(S P B \_K D P\right)$

\begin{tabular}{cccc}
\hline $\begin{array}{c}\text { Sample } \\
\text { ID }\end{array}$ & $\begin{array}{c}\text { Density, } \\
\mathrm{kg} / \mathrm{m}^{3}\end{array}$ & $\begin{array}{c}\text { Moisture } \\
\text { content, \% }\end{array}$ & $\begin{array}{c}\text { Aggregate crushing } \\
\text { value (ACV), \% }\end{array}$ \\
\hline SP 1 & 2733 & 0.057 & 12.2 \\
SP 2 & 2389 & 0.072 & 14.77 \\
SP 3 & 2628 & 0.13 & 18.37 \\
SP 4 & 1553 & 0.049 & 12.81 \\
\hline
\end{tabular}

The slake durability of the rock samples in Table 2 ranges between $80.12-91.72 \%$ and having a mean value of $87.17 \%$, thereby indicating medium durability of the rock.

Table 2. Slake durability test $\left(S_{-} P_{-}\right.$KDP $)$

\begin{tabular}{cccc}
\hline $\begin{array}{c}\text { Sample } \\
\text { ID }\end{array}$ & $\begin{array}{c}\text { \% retention } \\
\text { after } 1^{\text {st }} \text { cycle }\end{array}$ & $\begin{array}{c}\text { \% retention } \\
\text { after } 2^{\text {nd }} \text { cycle }\end{array}$ & Remarks \\
\hline SP 1 & 91.72 & 73.14 & Medium Durability \\
SP 2 & 89.2 & 68.43 & Medium Durability \\
SP 3 & 87.65 & 66.38 & $\begin{array}{c}\text { Medium Durability } \\
\text { Medium Durability } \\
\text { to low Durability }\end{array}$ \\
SP 4 & 80.12 & 55.74 & \\
\hline
\end{tabular}

The point load strength index of the rock range of 18.38-24.07 $\mathrm{MPa}$ with a mean value of $21.21 \mathrm{MPa}$ and the uniaxial compressive strength range of 275.73-336.60 MPa with a mean strength of $325.64 \mathrm{MPa}$. In Tables 3 and 4 respectively are a congruent indication that the rock is in the high strength class.

Table 3. Point load (SP_KDP)

\begin{tabular}{cccccc}
\hline $\begin{array}{c}\text { Sample } \\
\text { ID }\end{array}$ & $\begin{array}{c}\text { Specimen } \\
\text { width } \\
(W), \mathrm{mm}\end{array}$ & $\begin{array}{c}\text { Distance } \\
\text { btw platen } \\
(D), \mathrm{mm}\end{array}$ & $A, \mathrm{~m}^{2}$ & $\begin{array}{c}\text { Breaking } \\
\text { load, kN }\end{array}$ & $\begin{array}{c}\text { Point load } \\
\text { index, } \\
\mathrm{MPa}\end{array}$ \\
\hline SP 1 & 0.079 & 0.055 & 0.004345 & 84.9 & 22.44 \\
SP 2 & 0.076 & 0.069 & 0.005244 & 80.1 & 18.38 \\
SP 3 & 0.077 & 0.047 & 0.003619 & 65.8 & 19.94 \\
SP 4 & 0.060 & 0.054 & 0.00324 & 73.1 & 24.07 \\
\hline
\end{tabular}

Table 4. Uniaxial compressive strength (UCS) (SP_KDP)

\begin{tabular}{cccc}
\hline $\begin{array}{c}\text { Sample } \\
\text { ID }\end{array}$ & $\begin{array}{c}\text { Poisson } \\
\text { rate }\end{array}$ & Young Modulus, GPa & Peak stress, MPa \\
\hline SP 1 & 0.26 & $46.52 \times 10^{5}$ & 336.60 \\
SP 2 & 0.25 & $45.46 \times 10^{5}$ & 275.73 \\
SP 3 & 0.24 & $49.73 \times 10^{5}$ & 299.15 \\
SP 4 & 0.24 & $54.27 \times 10^{5}$ & 361.08 \\
\hline
\end{tabular}

Classification of rock $=$ High strength .

The Cerchar abrasivity index of the rock range of 2.8 and 3.5 with a mean value of 3.15 in Table 5, however, indicates medium to high abrasive strength of the rock. 
Table 5. Abrasive test

\begin{tabular}{ccc}
\hline $\begin{array}{c}\text { Sample } \\
\text { ID }\end{array}$ & $\begin{array}{c}\text { Cerchar abrasivity } \\
\text { index (CAI) }\end{array}$ & Classification \\
\hline SP 1 & 3.5 & High \\
SP 2 & 3.3 & High \\
SP 3 & 3.0 & Medium to High \\
SP 4 & 2.8 & Medium \\
\hline
\end{tabular}

The trend in Table 6 follows the high strength class as the rock's hardness ranges between 12.20-18.37, and having a mean value of 5.5 .

Table 6. Test for hardness

\begin{tabular}{ccc}
\hline $\begin{array}{c}\text { Sample } \\
\text { ID }\end{array}$ & Hardness class & Hardness \\
\hline SP 1 & Orthoclase & 6 \\
SP 2 & Orthoclase & 6 \\
SP 3 & Apatite & 5 \\
SP 4 & Apatite & 5 \\
\hline
\end{tabular}

Table 7 shows that porosity and water absorption of the rock with range values of $1.69-2.74 \%$ and $1-1.67 \%$ and mean values of 2.1 and $1.29 \%$ respectively are congruently low.

Table 7. Porosity, water absorption and brittleness

\begin{tabular}{cccc}
\hline $\begin{array}{c}\text { Sample } \\
\text { ID }\end{array}$ & $\begin{array}{c}\text { Apparent } \\
\text { porosity, } \%\end{array}$ & $\begin{array}{c}\text { Water absorption, } \\
\%\end{array}$ & $\begin{array}{c}\text { Brittleness value } \\
\text { (AIV), } \%\end{array}$ \\
\hline SP 1 & 1.69 & 1.17 & 5.17 \\
SP 2 & 2.74 & 1.67 & 8.0 \\
SP 3 & 2.04 & 1.33 & 10 \\
SP 4 & 1.78 & 1.00 & 5.5 \\
\hline
\end{tabular}

The rock's brittleness's range of $5.17-10 \%$ with a mean value of $7.17 \%$, however, differs with comparatively higher value. The presence of quartz, feldspar, and dark mafic minerals (mica and hornblende) with fine grained texture was indicated. There has been no visible plane of weakness, and they are defect free. The predominant mineral found in the sample is quartz. From the VES investigation shown in Table 8 , it is obvious that the site is divided by a high outcrop exposure at the central part and a third of the area lower down from the zero overburden to maximum depth of $2.4 \mathrm{~m}$ round the single cadastral unit.

Table 8. Nature and depth of earth layers

\begin{tabular}{ccccc}
\hline S/N & $\begin{array}{c}\text { Depth, } \\
\mathrm{m}\end{array}$ & $\begin{array}{c}\text { Thickness, } \\
\mathrm{m}\end{array}$ & Lithology & Remark \\
\hline 1. & $0.3-0.9$ & 0.06 & Top soil & $\begin{array}{c}\text { Brownish } \\
\text { loamy }\end{array}$ \\
\hline 2. & $0.9-1.4$ & 0.5 & $\begin{array}{c}\text { Lateritic } \\
\text { clay }\end{array}$ & $\begin{array}{c}\text { Reddish brown } \\
\text { rarely sandy clay } \\
\text { loam (lateritic) }\end{array}$ \\
\hline 3. & $1.4-2.4$ & 1.1 & $\begin{array}{c}\text { Weathered } \\
\text { layer }\end{array}$ & $\begin{array}{c}\text { Weathered micaceous } \\
\text { and banded gneiss } \\
\text { materials gravelly } \\
\text { sandy feldspathic }\end{array}$ \\
\hline 4. & 2.4 & $\begin{array}{c}\text { To } \\
\text { basement }\end{array}$ & $\begin{array}{c}\text { Fresh } \\
\text { basement }\end{array}$ & $\begin{array}{c}\text { Weathered soil of } \\
\text { granitic origin to } \\
\text { basement rock }\end{array}$ \\
\hline
\end{tabular}

The VES filed curves have been interpreted qualitatively using simple curves shapes with graphical model curves or quantitative computer modeling as shown in Figure 7.

The field data captured on acquisition read between three (3) to four (4) layer models all of which range between $2-10 \%$ resistivity and thickness accuracy. The area under study is made up of thick to moderate depth to basement at the NorthEastern part, while the outcrop is of zero overburden at the central part with a very light over-burden material covering the North-Western and Southern part as shown in Figures 8 and 9.

(a)

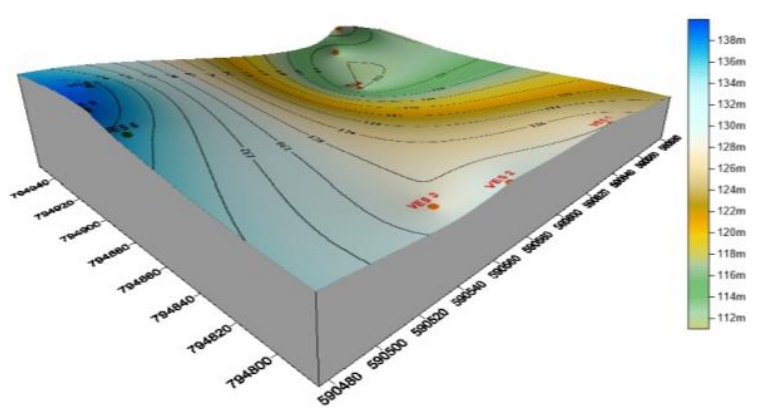

(b)

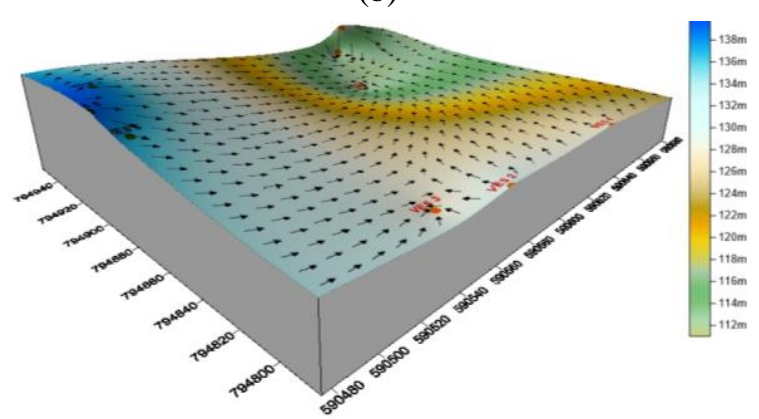

Figure 8. 3D integrated surface relief maps: (a) VES locations; (b) the ground water flowing direction

(a)

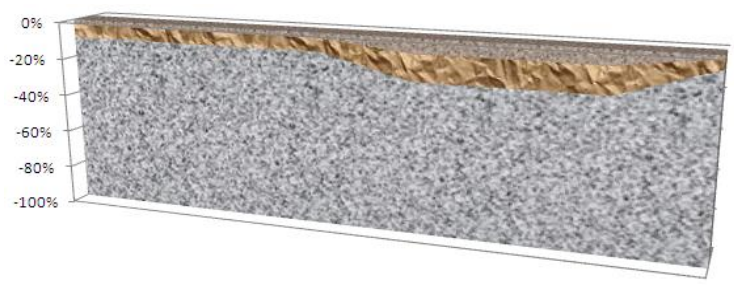

(b)

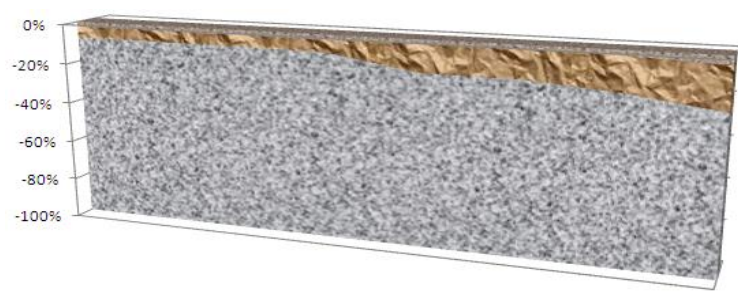

(c)

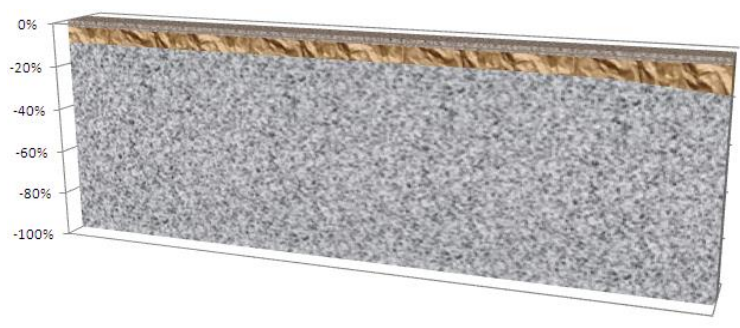

Figure 9. 3D geo-electric sections: (a) eastern section VES 6-VES 7; (b) western section VES 1-VES 5; (c) of the northern Section VES 4 VES 8 
(a)

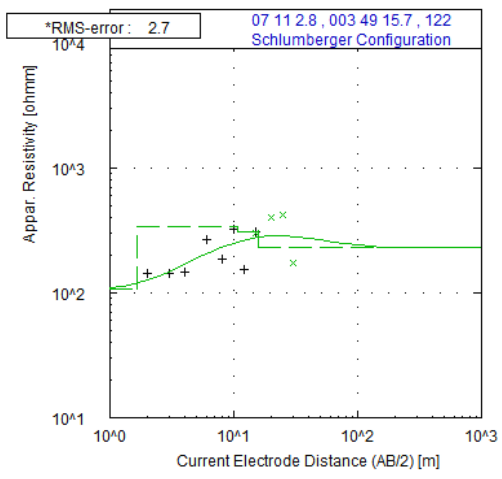

(c)

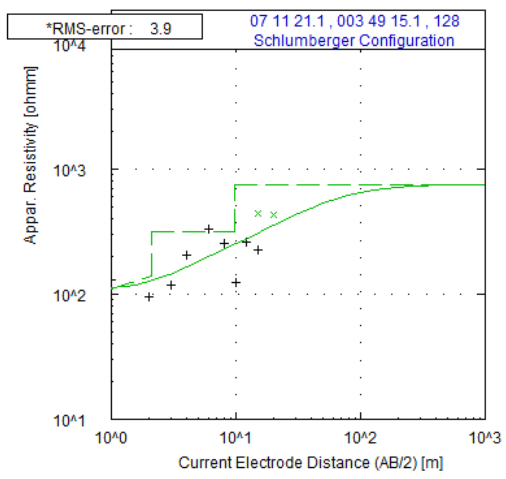

(e)

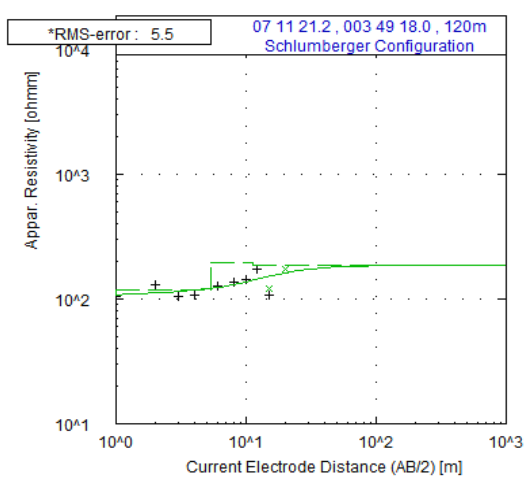

(b)
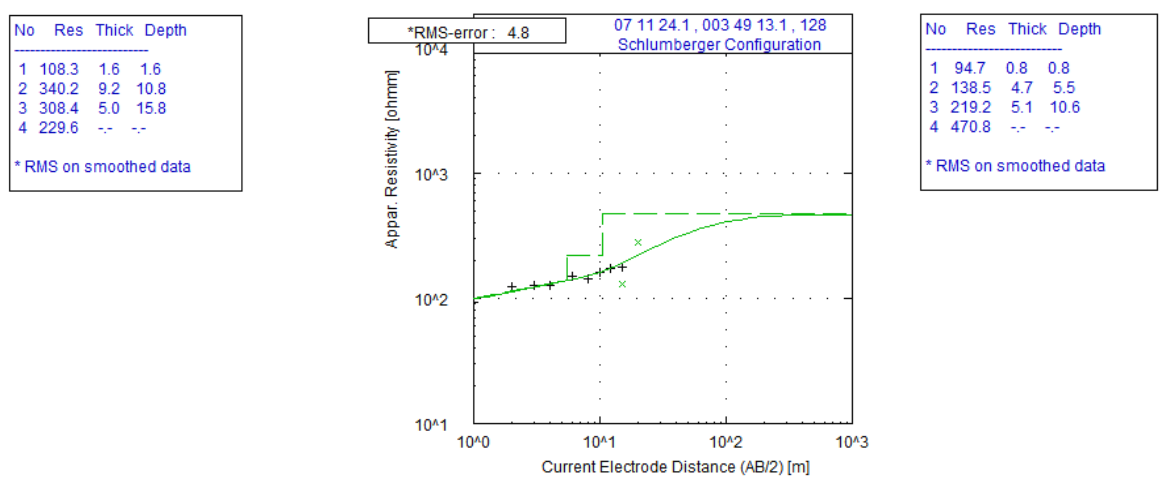

(d)
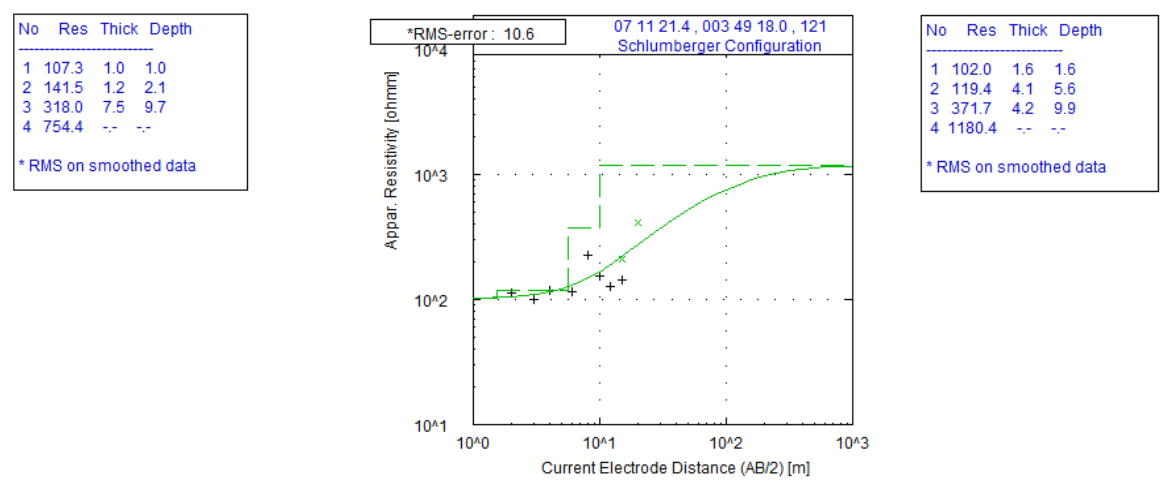

(f)
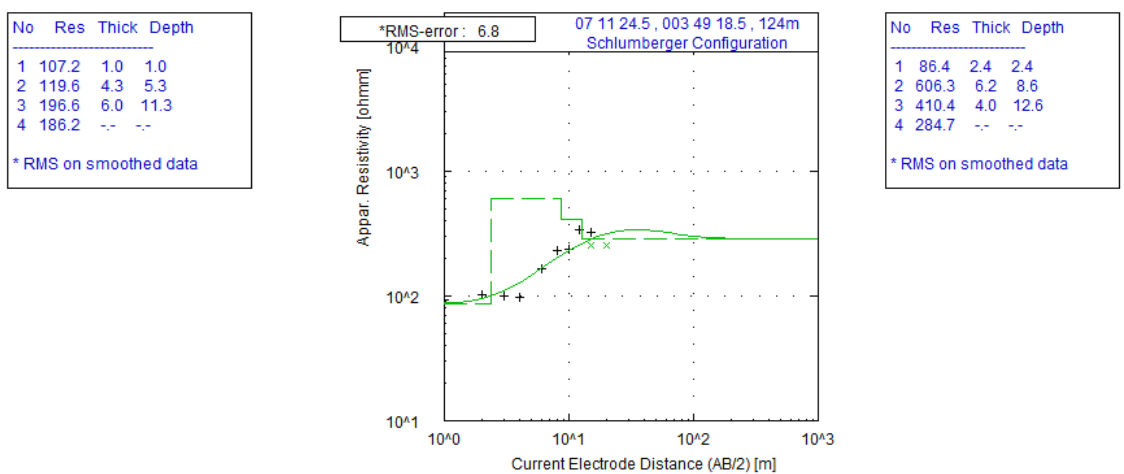

(g)

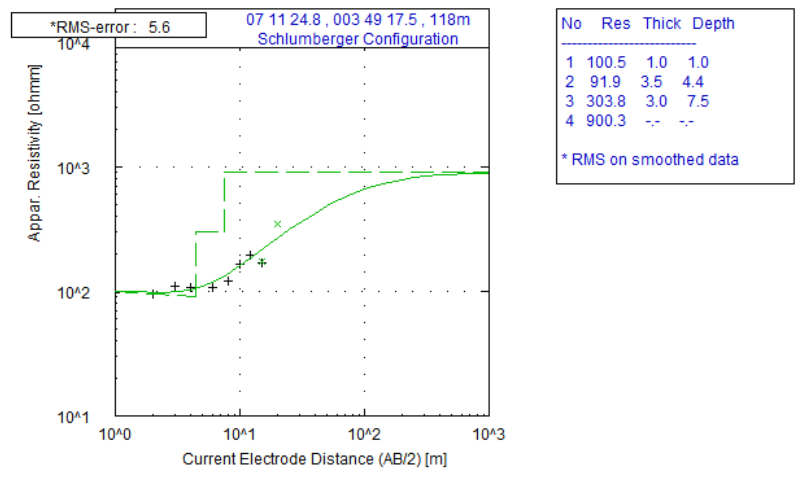

Figure 7. VES curves: (a) 1; (b) 2; (c) 3; (d) 4; (e) 5; (f) 6; (g) 7

\section{Conclusions}

The study on the physical and mechanical properties of the granite outcrop in Onikoko community in Oyo State, Nigeria, leads to the following conclusions:
1. Granite rocks must possess adequate physical and mechanical characteristics which make them suitable for construction and engineering purposes.

2. The strength characterization of granite outcrop has shown that its uniaxial compressive strength, point load 
strength index and other physico-mechanical properties evaluated in this study have values which fall within the American Standard for Measuring Materials (ASTM, D 2487) and International Society for Rock Mechanics (ISRM, 1985) standards.

3. The mineral reserve estimation has also indicated that the granite outcrop has a reserve that is large enough to cater for the establishment of a quarry with a life span of forty years.

4. The granite outcrop in the study area is an embedded massive deposit covering wide areas of land thereby indicating that the outcrop is technically and commercially quarriable, with less environmental impact.

5. It is, therefore, evident that the granite outcrop in the study area is suitable for the establishment of a granite quarry.

\section{Acknowledgements}

This research was funded by Geocardinal Engineering Services Limited, Abuja, Nigeria. The authors express deep appreciation to the management of the company. The site personnel of the company are equally appreciated for their support during the field work.

\section{References}

[1] Wahab, G.M.A., Gouda, M., \& Ibrahim, G. (2019). Study of physical and mechanical properties for some of Eastern Desert dimension marble and granite utilized in building decoration. Ain Shams Engineering Journal, 10(4), 907-915. https://doi.org/10.1016/j.asej.2019.07.003

[2] Adeyi, G.O., Mbagwu, C.C., Ndupu, C.N., \& Okeke, O.C. (2019). Production and uses of crushed aggregates: An overview. International Journal of Advanced Academic Research/Sciences, Technology and Engineering, 5(8), 92-110.

[3] Irfan, T.Y. (1994). Aggregate properties and resources of granitic rocks for use in concrete in Hong Kong. Quarterly Journal of Engineering Geology and Hydrogeology, 27(1), 25-38. https://doi.org/10.1144/gsl.qjegh.1994.027.p1.05

[4] Naeem, M., Khalid, P., Sanaullah, M., \& Zia ud Din. (2014). Physiomechanical and aggregate properties of limestones from Pakistan. Acta Geodaetica et Geophysica, 49(3), 369-380. https://doi.org/10.1007/s40328014-0054-8

[5] Panova, E.G., Vlasov, D.Y., \& Luodes, H. (2014). Evaluation of the durability of granite in architectural monuments. Report of Investigation. Espoo, Finland: Geological Survey of Finland, 97 p.

[6] Holland, T. (2001). Calculation of phase relations involving haplogranitic melts using an internally consistent thermodynamic dataset. Journal of Petrology, 42(4), 673-683. https://doi.org/10.1093/petrology/42.4.673

[7] Pacheco Torgal, F., \& Castro-Gomes, J.P. (2006). Influence of physical and geometrical properties of granite and limestone aggregates on the durability of a C20/25 strength class concrete. Construction and Building Materials, 20(10), 1079-1088. https://doi.org/10.1016/j.conbuildmat.2005.01.063
[8] Petrounias, P., Giannakopoulou, P., Rogkala, A., Stamatis, P., Lampropoulou, P., Tsikouras, B., \& Hatzipanagiotou, K. (2018). The effect of petrographic characteristics and physico-mechanical properties of aggregates on the quality of concrete. Minerals, 8(12), 577. https://doi.org/10.3390/min8120577

[9] Dean, S.W., Takarli, M., \& Prince-Agbodjan, W. (2008). Temperature effects on physical properties and mechanical behavior of granite: experimental investigation of material damage. Journal of ASTM International, 5(3), 100464. https://doi.org/10.1520/jai100464

[10] Korman, T., Bedekovic, G., Kujundzic, T., \& Kuhinek, D. (2014) Impact of physical and mechanical properties of rocks on energy consumption of jaw crusher. Physicochemical Problems of Mineral Processing, 51(2), 461-475.

[11] Adebayo, B., \& Adetula, B. (2013). Evaluation of physical and mechanical properties of rock for drilling condition classification. World Journal of Engineering, 10(4), 359-366. https://doi.org/10.1260/17085284.10.4.359

[12] Agyeman, S., Assiamah, S., \& Twumasi, G. (2019). Correlations of physicomechanical properties of quarry aggregates - the case of two quarries in Ghana. Global Journal of Engineering Sciences, 2(1), 1-11. https://doi.org/10.33552/GJES.2019.02.000530

[13] Adekoya, J.A., Kehinde-Phillips, O.O., \& Odukoya, A.M. (2011) Geological distribution of mineral resources in South-Western Nigeria. Journal of Mining and Geology, 47(1), 1-13.

[14] Ogunyele, A., \& Akingboye, A. (2018). Tin mineralisation in Nigeria: A review. Environmental and Earth Sciences Research Journal, 5(1), 15-23. https://doi.org/10.18280/eesrj.050103

[15] Alayande, S.O., Mubiayi, M.P., Makhatha, M.E., \& Derek, R. (2015). Experimental characterization of physicochemical and geological properties of granite from Olowu, Ibadan, Oyo State, Nigeria. Proceedings of the World Congress on Mechanical, Chemical, and Material Engineering. Paper No. 337.

[16] Cull, S. (2009). Rocks and minerals. New York, United States: Chelsea House Publishers, The Franklin Institute, 102 p.

[17] Brown, E.T. (1981). Rock characterization, testing and monitoring (p. 75-105). ISRM Suggested methods. Commission on Testing Methods. International Society for Rock Mechanics. Oxford, United Kingdom: Pergamon Press.

[18] ASTM. (2001). Standard test method for determination of rock hardness by rebound hammer method. Designation D 5873. West Conshohocken, United States: American Society for Testing and Materials International.

[19] Adebayo, B., Opafunso, Z.O., \& Akande, J.M. (2010). Drillability and strength characteristics of selected rocks in Nigeria. AU Journal of Technology, 14(1), 56-60.

[20] Jacobsson, L. (2007). Forsmark site investigation borehole KFM01C uniaxial compression test of intact rock. Boras, Sweden: Swedish National Testing and Research Institute, $52 \mathrm{p}$.

[21] Tiryaki, B. (2006). Evaluation of the indirect measures of rock brittleness and fracture toughness in rock cutting. The Journal of the South African Institute of Mining and Metallurgy, (106), 407-424.

[22] Aydin, A. (2009). ISRM Suggested method for determination of the Schmidt hammer rebound hardness: Revised version. International Journal of Rock Mechanics and Mining Sciences, 46(3), 627-634. https://doi.org/10.1016/j.ijrmms.2008.01.020

\section{Дослідження фізичних і механічних властивостей відслонених гранітних порід у кар'єрі Онікоко, штат Ойо, Південно-Східна Нігерія}

\section{Л.К. Салаті, Дж.Т. Адеємо}

Мета. Дослідити фізичні та механічні властивості відслонених гранітних порід в кар'єрі Онікоко, штат Ойо, ПівденноСхідна Нігерія.

Методика. Зразки гранітної породи були взяті з відслонення для лабораторного визначення їх фізико-механічних властивостей відповідно до Американського стандарту для випробувань матеріалів (ASTM) D 2487 та Міжнародного товариства механіків гірських порід (ISRM). Оцінка запасів гранітного відслонення включала геологічні та геофізичні дослідження, які містили геоелектричні дослідження, в основному із застосуванням методу електричного опору з використанням конфігурації вертикального електричного зондування Шлюмберже (VES) за допомогою вимірювача опору.

Результати. Встановлено, що фізико-механічні властивості гранітних зразків відповідають міжнародним стандартам. Виявлено, що відслонення граніту в районі дослідження являє собою залягаюче масивне родовище, яке охоплює великі площі землі, що вказує на те, що відслонення $є$ технічно і комерційно придатним для видобутку корисних копалин 3 меншим впливом на навколишне середовище. Проведено оцінку мінеральних запасів родовища, яка дозволила визначити передбачуваний термін експлуатації гранітного кар'єру - 40 років, що підтверджує наявність значних покладів граніту в цьому районі та свідчить про перспективність кар'єрної розробки.

Наукова новизна. Встановлено показники фізичних і механічних характеристик гранітів кар'єра Онікоко, де найбільш важливе значення мають їх високі міцнісні характеристики, що доводить їх придатність для використання в будівництві й промисловості. 
Практична значимість. Результати даного дослідження представляють інтерес для потенційних інвесторів і підприємців, які планують вести кар'єрну розробку граніту в Онікоко, що також приверне увагу уряду до потреб місцевого населення для створення базової інфраструктури.

Ключові слова: відслонення граніту, фізико-механічні властивості, експлуатачія кар'єру, міџність, геофізичні дослідження

\section{Исследование физических и механических свойств обнаженных гранитных пород в карьере Оникоко, штат Ойо, Юго-Восточная Нигерия}

\section{Л.К. Салати, Дж.Т. Адеемо}

Цель. Исследовать физические и механические свойства обнаженных гранитных пород в карьере Оникоко, штат Ойо, ЮгоВосточная Нигерия.

Методика. Образцы гранитной породы были взяты из обнажения для лабораторного определения их физико-механических свойств в соответствии с Американским стандартом для испытаний материалов (ASTM) D 2487 и Международным обществом механиков горных пород (ISRM). Оценка запасов гранитного обнажения включала геологические и геофизические исследования, которые содержат геоэлектрические исследования, в основном с применением метода электрического сопротивления с использованием конфигурации вертикального электрического зондирования Шлюмберже (VES) с помощью измерителя сопротивления.

Результаты. Установлено, что физико-механические свойства гранитных образцов соответствуют международным стандартам. Выявлено, что обнажение гранита в районе исследования представляет собой залегающее массивное месторождение, охватывающее большие площади земли, что указывает на то, что обнажение является технически и коммерчески пригодным для добычи полезных ископаемых с меньшим воздействием на окружающую среду. Проведена оценка минеральных запасов месторождения, которая позволила определить предполагаемый срок эксплуатации гранитного карьера - 40 лет, что подтверждает наличие обширной залежи гранита в этом районе и свидетельствует о перспективности карьерной разработки.

Научная новизна. Установлены показатели физических и механических характеристик гранитов карьера Оникоко, где наиболее важное значение имеют их высокие прочностные характеристики, что доказывает их пригодность для использования в строительстве и промышленности.

Практическая значимость. Результаты данного исследования представляют интерес для потенциальных инвесторов и предпринимателей, которые будут вести карьерную разработку гранита в Оникоко, что также привлечет внимание правительства к нуждам местного населения для создания базовой инфраструктуры.

Ключевые слова: обнажение гранита, физико-механические свойства, эксплуатация карьера, прочность, геофизические исследования 